\title{
PERBEDAAN ALUR ANTARA NASKAH DRAMA \\ NENEK TERCINTA KARYA ARIFIN C. NOER DAN PERTUNJUKANNYA
}

\author{
IBROHIM. ${ }^{1}$, TURAHMAT, ${ }^{2}$, OKTARINA PUSPITA WARDANI ${ }^{3}$ \\ Prodi PBSI, FKIP, Universitas Islam Sultan Agung Semarang
}

brandalgema@gmail.com¹, lintangsastra@unissula.ac.id², oktarinapw@unissula.ac.id²

\begin{abstract}
Abstrak
Penelitian ini dilatarbelakangi karena perbedaan alur dalam naskah drama Nenek Tercinta yang ditulis oleh Arifin C. Noer dan pertunjukan yang telah dilaksanakan di Universitas PGRI Semarang pada acara festival lomba drama tingkat SMA/SMK sederajat yang digelar oleh Teater Gema Semarang. Penceritaan dalam pertunjukan Nenek Tercinta garapan Alvianto dengan menghilangkan tokoh dukun serta beberapa tokoh lain. Masalah yang diangkat dalam penelitian ini adalah bagaimanakah perbedaan alur antara naskah drama Nenek Tercinta karya Arifin C. Noer dan pertunjukannya. Adapun tujuan penelitian ini adalah untuk mendeskripsikan perbedaan alur antara naskah drama Nenek Tercinta karya Arifin C. Noer dan pertunjukannya. Metode yang digunakan dalam penelitian ini yaitu metode deskriptif analisis. Pendekatan objektif digunakan sebagai perhatian pada unsur-unsur yang dikenal dengan analisis intrinsik. Sumber data dalam penelitian ini adalah naskah drama Nenek Tercinta karya Arifin C. Noer dan naskah drama adaptasi teater Sukma SMK N 2 Semarang yang di dalamnya terdapat unsur-unsur instrinsik dan ekstrinsik. Wujud data dalam penelitian ini adalah dialog, kata, kalimat, dan hasil analisis berupa perbedaan alur dalam naskah drama Nenek Tercinta karya Arifin C. Noer dan pertunjukannya. Pengumpulan data dengan menggunakan metode studi pustaka. Analisis perbedaan alur antara naskah drama Nenek Tercinta karya Arifin C. Noer dan pertunjukannya, peneliti menyediakan data yang berupa kutipan peristiwa yang dialami oleh tokoh-tokoh yang berisikan halhal yang bersifat ambigu kemudian dianalisis. Penyajian hasil analisis data dilakukan secara deskriptif dengan menggunakan kata-kata biasa tanpa disertai dengan lambang. Pemaparan hasil analisis data berupa perbedaan alur antara naskah drama Nenek Tercinta karya Arifin C. Noer dan pertunjukannya. Dari hasil penelitian diketahui bahwa naskah drama Nenek Tercinta karya Arifin C. Noer memiliki alur erat di mana jalinan peristiwa sangat padu dan tidak meninggalkan salah satu unsur pembentukan alur: penampilan masalah, perumitan (konflik), puncak masalah (klimaks), peleraian, dan kesimpulan cerita. Adapun dalam pertunjukannya alur yang digunakan adalah alur longgar dengan meninggalkan salah satu peristiwa penting yaitu keberadaan dukun sebagai perumitan (konflik). Berdasarkan pengakhirannya, naskah drama Nenek Tercinta karya Arifin C. Noer menggunakan alur tertutup di mana cerita hanya sampai kepada dukun yang pamit karena sudah menyelesaikan urusan dan menyakan bahwa yang berkuasa adalah dalang dari segala dalang, sedangkan naskah pertunjukannya menggunakan alur terbuka yang akhir ceritanya diserahkan kepada penonton.
\end{abstract}

Kata kunci: naskah drama, alur, drama. 


\begin{abstract}
This research is based on the difference of the flow in the script of the drama of the Beloved Grandma written by Arifin C. Noer and the performances that have been held at the University of PGRI Semarang in the festival of drama competition of high school / vocational high school level which is titled by Teater Gema Semarang, telling story in the show of beloved grandmother Alvianto claimed by removing the dukun figure as well as several other figures. The formulation of the problem in this research is how is the difference between the plot of Uncondited Grandma drama masterpiece Arifin C. Noer and the show? The purpose of this study is to describe the difference between the plot of drama of Uncondited Grandma's masterpiece by Arifin C. Noer and the show. The method used in this research using descriptive analysis method. The objective approach is used as attention to elements known as intrinsic analysis. Sources of data in this study is the work of playwright Loving grandmother Arifin C. Noer and playwright theatrical adaptations Sukma SMK N 2 Semarang in which there are elements of intrinsic and extrinsic. The form of data in this research is written data in the form of dialogue, word, sentence, and result of analysis in the form of difference of flow in drama script of Grandma Beloved by Arifin C. Noer and its show. Data collection using literature study method. Analyzing the difference in flow between the script of Grandma Tercinta's drama by Arifin C. Noer and his show, the researcher provided data in the form of quotation of the events experienced by the figures containing the things that are ambiguous, then analyzed. The presentation of the results of data analysis is done descriptively using ordinary words without accompanying the symbol. The exposure of the data analysis resulted in the difference of the flow between the script of Grandma Tercinta's drama by Arifin C. Noer and the show. The results show that Arifin C. Noer's playful Grandma drama script has a tight groove, where the fabric of events is very solid and does not leave any of the elements of flow formation: the appearance of the problem, the complexity (conflict), the peak of the problem (klimak), the divorce, and the conclusion of the story. While the show, using the loose groove by leaving one of the important events of the existence of shaman as a complication (conflict). Based on the termination, Arifin C. Noer's Unlawful Script drama script uses a closed path where the story only goes to the dukun who excuses him for completing the affairs and declares that Yang is the master of all dalangs. While the script performances using an open groove that the end of the story submitted to the audience.
\end{abstract}

Keywords: drama script, plot, drama.

\title{
PENDAHULUAN
}

Salah satu jenis karya sastra adalah naskah drama. Wujud fisik sebuah naskah adalah dialog atau ragam tutur yang merupakan ragam sastra. Bahasa dan maknanya tunduk pada konvensi sastra. Naskah drama dapat dijadikan bahan studi sastra, dapat dipentaskan, dan dapat di pagelarkan dalam media audio, berupa sandiwara radio atau kaset. Pagelaran dapat juga di depan publik langsung dan juga pada televisi. Sebuah naskah drama juga merupakan komposisi seni kepenulisan Yudiaryani (2015:63). Keunggulan naskah drama terdapat pada konflik yang dibangun. Konflik untuk menentukan lika-liku ke arah klimaks yang melahirkan suspensi dan kejutan.

Naskah drama Nenek Tercinta merupakan naskah drama yang ditulis oleh Arifin C. Noer yang 
di dalamnya terdapat konflik yang menuju arah klimaks. Konfliks tersebut meggambarkan keserakahan dari anak-anak serta cucu nenek yang menginginkan harta warisan. Kematian nenek telah direncanakan oleh anak bernama Lastri dengan mendatangkan dukun terkenal dari daerah sekitar. Berbeda dalam pertunjukan yang telah dilaksanakan di Universitas PGRI Semarang pada acara festival lomba drama tingkat SMA/SMK sederajat yang digelar oleh Teater Gema Semarang, penceritaan dalam pertunjukan Nenek Tercinta garapan Alvianto dengan menghilangkan tokoh dukun serta beberapa tokoh lain yang pada akhirnya membuat alur cerita menjadi ambigu. Tokoh utama dalam pertunjukan menjadi tidak jelas. Serta konflik yang ditunjukkan belum menuju klimaks. Alur yang seharusnya dapat membuat jalan cerita dalam naskah drama menjadi menarik, tetapi menjadi kurang menarik.

Alur pada naskah drama Nenek Tercinta Arifin C. Noer menyajikan penceritaan yang kompleks, serta terdapat banyak tikaian sebagai konflik baik batin maupun fisik, sedangkan alur pada pementasannya menjadi kurang begitu jelas. Hal ini disebabkan karena penghilangan beberapa adegan yang seharusnya dapat ditampilkan. Penghilangan tokoh dukun juga sangat mempengaruhi alur pada cerita pementasan. Perbedaan alur cerita Nenek Tercinta karya Arifin C. Noer baik dalam naskah drama dan pertunjukannya membuat peneliti melakukan analisis yang nantinya akan jelas perbedaan alur yang disajikan baik dalam naskah maupun dalam pertunjukannya. Peneliti sudah melakukan observasi dengan melihat pementasan Nenek Tercinta karya Arifin C. Noer yang diselenggarakan di Universitas PGRI Semarang yang disutradarai oleh Alvianto. Dari h asil observasi tersebut diketahui terdapat perbedaan yang jelas antara naskah dan pertunjukannya.

Alasan pemilihan pertunjukan Nenek Tercinta karya Arifin C. Noer yang diselenggarakan di Universitas PGRI Semarang dikarenakan terdapat perbedaan antara naskah drama dengan pertunjukannya. Pertunjukan drama Nenek Tercinta karya Arifin C. Noer dilakukan di Universitas PGRI Semarang yang diselenggarakan oleh Teater Gema dalam festival pelajar Se-Jawa Tengah. SMK N 2 Semarang mementaskan drama Nenek Tercinta Arifin C. Noer. Hal tersebut membuat peneliti mempunyai ide untuk melakukan penelitian dengan mencari perbedaan alur antara naskah drama Nenek Tercinta karya Arifin C. Noer dengan pertunjukan yang dilakukan oleh siswa SMK N 2 Semarang.

Arifin Chairin Noer lahir di Cirebon, Jawa Barat, 10 Maret 1941 dan meninggal di Jakarta, 28 Mei 1995 pada umur 54 tahun atau lebih dikenal sebagai Arifin C. Noer. Dia adalah sutradara teater dan film asal Indonesia yang beberapa kali memenangkan Piala Citra untuk penghargaan film terbaik dan penulis skenario terbaik (Wikipedia, 2016). Ia menamatkan SD di Taman Siswa, Cirebon, SMP Muhammadiyah, Cirebon, lalu SMA Negeri Cirebon tetapi tidak tamat, kemudian pindah ke SMA Jurnalistik, Solo. Setelah itu kuliah di Fakultas Sosial Politik Universitas Cokroaminoto, Yogyakarta. Tahun 1972-1973 mengikuti International Writing Program di Universitas Iowa, Iowa City, Amerika Serikat.

Naskah drama karyanya antara lain Lampu Neon atau Nenek Tercinta, telah memenangkan sayembara Teater Muslim pada tahun 1987. Kemudian saat kuliah di Universitas Cokroaminoto Solo, ia bergabung dengan Teater Muslim yang dipimpin Mohammad Diponegoro (Wikipedia 2016). Ia kemudian hijrah ke Jakarta dan mendirikan Teater Kecil pada tahun 1968. Teater Kecil berhasil mementaskan cerita, dongeng, yang seperti bernyanyi. Tentang orang-orang yang terempas, pencopet, pelacur, orang-orang kolong. Mencuatkan protes sosial yang transendental, tetapi kocak dan religius. 
Tingkat keterampilan penulis drama ditentukan oleh keterampilan menjalin konfliks yang diwarnai oleh kejutan dan suspensi yang belum pernah diciptakan oleh pengarang lain. Yudiaryani (2015:63) menjelaskan bahwa drama merupakan komposisi verbal yang diadaptasi serta diolah untuk kepentingan pertunjukan teatrikal, biasanya berbentuk kata-kata yang diucapkan dan di dalamnya berisi beberapa arahan laku serta detail pertunjukan.

Unsur pembangun sebuah naskah drama yang membentuk sebuah totalitas dapat dikelompokan menjadi dua bagian, yaitu unsur intrinsik dan unsur ekstrinsik (Waluyo, 2001:24). Unsur instrinsik adalah unsur yang membangun karya sastra itu sendiri, misalnya tema, tokoh dan penokohan, latar, dan gaya bahasa. Unsur ekstrinsik adalah unsur yang membangun karya sastra dari luar. Unsur ekstrinsik terdiri dari sosial, budaya, dan moral. Unsur tersebut mengandung nilai-nilai atau pesan yang ada dalam cerita.

Penulis menganggap analisis naskah drama Nenek Tercinta Karya Arifin C. Noer dan pertunjukannya sangat menarik dilakukan untuk mengetahui perbedaan alur secara jelas. Perbedaan alur tersebut yang nantinya akan mempengaruhi esensi dari cerita yang disajikan. Tentunya, konflikkonflik yang disajikan dalam naskah dan pertujukannya akan sangat berbeda. Berkurangnya konflikkonflik yang disajikan akan mempengaruhi keutuhan cerita.

\section{LANDASAN TEORI}

\section{Hakikat Drama}

Drama merupakan tiruan kehidupan manusia yang diproyeksikan di atas panggung. Terkadang konflik yang disajikan dalam drama sama dengan konflik batin penonton. Drama adalah potret kehidupan manusia, potret suka duka, pahit manis, hitam putih kehidupan manusia (Waluyo, 2001:1). Menurut Abrams (dalam Dewojati, 2010:8) drama merupakan salah satu bentuk sastra yang dibentuk untuk teater, di dalamnya aktor memainkan peran karakter, memainkan aksi, dan mengucapkan dialog tertulis.

Berdasarkan pendapat para ahli tersebut, maka dapat disimpulkan bahwa drama merupakan salah satu bentuk sastra yang dibentuk untuk teater, di dalamnya aktor memainkan peran karakter, memainkan aksi, serta mengucapkan dialog tertulis yang memunculkan konflik atau tikaian.

\section{Naskah Drama}

Apabila menyebut istilah drama, maka ada dua kemungkinan, yaitu drama naskah dan drama pentas yang keduanya bersumber pada drama naskah. Naskah drama dapat dijadikan bahan studi sastra, dapat dipentaskan, dan dapat dipagelarkan dalam media audio berupa sandiwara radio atau kaset.

Naskah drama dapat diberi batasan sebagai bagian karya sastra yang ditulis dalam bentuk dialog yang didasarkan pada konflik batin dan memiliki kemungkinan untuk dipentaskan (Waluyo, 2001:2). Wujud fisik sebuah naskah adalah dialog atau ragam tutur yang merupakan ragam sastra. Bahasa dan maknanya tunduk pada konvensi sastra. 


\section{Unsur-unsur Drama}

1. Tema dan Amanat

Tema merupakan gagasan pokok yang terkandung dalam drama (Waluyo, 2001:24). Tema berhubungan dengan premis dari drama tersebut yang berhubungan pula dengan nada dasar dari sebuah drama dan sudut pandang yang dikemukakan oleh pengarangnya. Sudut pandang ini sering dihubungkan dengan aliran yang dianut oleh pengarang.

2. Penokohan

Penokohan merupakan upaya penampilan 'tokoh' sebagai pembawa peran watak tokoh dalam suatu pementasan lakon (Satoto, 2012:40). Penokohan harus mampu melahirkan citra tokoh, karena tokoh harus dihidupkan. Penokohan bisa dilakukan menggunakan berbagai cara.

3. Alur (plot)

Alur merupakan jalinan cerita atau kerangka dari awal hingga akhir yang merupakan jalinan konflik antara dua tokoh yang berlawanan (Waluyo, 2001:8). Konflik itu berkembang karena kontradiksi para pelaku.

Menurut Abrams (dalam Satoto, 2012:44) alur dalam lakon tidak hanya bersifat verbal, tetapi juga bersifat gerak fisik. Alur dilihat dari segi mutunya (kualitatifnya) dibedakan menjadi dua sebagai berikut.

1). Alur erat atau ketat merupakan jalinan peristiwa yang sangat padu dalam karya sastra.

2). Alur longgar adalah rangkaian peristiwa yang tidak padu. Meniadakan salah satu peristiwa, dan tidak akan mengganggu keutuhan serta jalannya cerita.

Alur dilihat dari segi jumlahnya (kuantitatif) dapat dibedakan menjadi dua macam, yaitu alur tunggal dan alur ganda. Pada lakon wayang biasanya menggunakan alur ganda.

Menurut Satoto (2012:44) ada bermacam alur sebagai berikut.

1). Alur menanjak atau rising plot, yakni jalinan peristiwa dalam karya sastra yang sifatnya semakin menanjak.

2). Alur menurun atau falling plot, yaitu jalinan peristiwa dalam karya sastra yang semakin menurun sifatnya.

3). Alur maju atau progresive plot, yaitu jalinan peristiwa karya sastra yang beruntun dan berkesinambungan dari segi kronologi dari tahap awal; sampai tahap akhir cerita, yaitu melalui tahap-tahap, pemaparan atau perkenalan, penggawatan, klimaks atau puncak, peleraian, serta penyelesaian.

4). Alur mundur atau regressive plot, merupakan jalinan peristiwa dalam karya sastra yang urutan atau tahapannya dimulai dari akhir menuju tahap-tahap peleraian, puncak, perumitan, baru merambah perkenalan.

5). Alur lurus atau straight plot yaitu jalinan peristiwa suatu karya sastra yang runtut, dari alur maju maupun alur mundur.

6). Alur patah atau break plot, merupakan jalinan peristiwa dalam suatu karya sastra yang 
penahapannya tidak runtut, tetapi patah-patah.

7). Alur sirkuler atau circular plot, yakni alur lingkar.

8). Alur linear atau linear plot, yaitu alur lurus.

9). Alur episodik atau episodic plot, yaitu jalinan peristiwanya tidak lurus, tetapi patah-patah. Ini merupakan alur kecil dan merupakan episode dari cerita panjang.

Jenis alur dapat dikelompokkan dengan menggunakan berbagai kriteria. Berdasarkan kriteria urutan waktu menurut Hariyanto (2000:39) alur dikelompokkan sebagai berikut.

1). Alur Maju

Alur maju atau alur kronologis, alur lurus atau alur progresif menyajikan peristiwa secara kronologis, maju, secara runtut dari awal, tengah hingga akhir.

2). Alur Mundur

Alur mundur disebut juga alur tak kronologis, sorot balik, regresif, atau flash-back adalah peristiwa-peristiwa yang ditampilkan dari tahap akhir atau tengah dan baru kemudian tahap awalnya.

Menurut Hariyanto (2000:39) alur dapat dibedakan menjadi kriteria jumlah sebagai berikut.

1). Alur Tunggal

Dalam cerita drama yang memilih alur ini biasanya menampilkan seorang tokoh protagonis. Cerita hanya mengikuti perjalanan hidup tokoh tersebut.

2). Alur Jamak

Dalam alur jamak, biasanya cerita drama menampilkan tokoh protagonis lebih dari satu. Perjalanan hidup tiap tokoh ditampilkan.

Berdasarkan kriteria cara pengakhirannya menurut Hariyanto, (2000:39) alur dapat dibedakan menjadi sebagai berikut.

1). Alur Tertutup

Dalam drama yang beralur tertutup, penampilan kisahnya diakhiri dengan kepastian atau secara jelas.

2). Alur Terbuka

Dalam drama yang beralur terbuka, penampilan kisahnya diakhiri secara tidak pasti, tidak jelas, serba mungkin. Jadi, akhir ceritanya diserahkan kepada imajinasi pembaca atau penonton.

\section{Setting (latar)}

Setting atau tempat kejadian cerita sering pula disebut latar cerita (Waluyo, 2001:23). Penentuan ini harus secara cermat, karena drama naskah juga memberikan kemungkinan untuk dipentaskan. Setting biasanya meliputi tiga dimensi, yaitu tempat, ruang, dan waktu. Istilah 'latar' (setting) dalam arti yang lengkap meliputi aspek ruang dan waktu terjadinya peristiwa. 


\section{METODE PENELITIAN}

Metode dalampenelitian sastra adalah cara yang dipilih oleh penelitidengan mempertimbangkan bentuk, isi, dan sifat sastra sebagai subjek kajian (Endraswara, 2006:8). Penggunaan metode dalam suatu penelitian bertujuan agar penelitian tersebut terencana dengan sistematis dan hasil dari penelitian tersebut dapat dipertanggungjawabkan.

\section{Metode Deskriptif Analisis}

Menurut Ratna (2012:53) analisis deskriptifadalah penguraian karya sastra atas unsur-unsurnya dengan cara mendeskripsikan fakta-fakta dilanjut menguraikannya serta memberi pemahaman serta penjelasan secukupnya.

Metode ini digunakan untuk mendeskripsikan alur yang terdapat dalam naskah drama Nenek Tercinta karya Arifin C. Noer dan alur yang terdapat dalam pertunjukannya.

\section{Pendekatan Objektif}

Pendekatan objektif merupakan pendekatan yang bergantung pada karya sastra. Menurut Ratna (2012:73) pendekatan objektif dilakukan dengan memusatkan perhatian atas unsur-unsur atau biasa disebut analisis intrinsik. Unsur-unsur intrinsik karya sastra akan dieksploitasi secara maksimal.

\section{Sumber Data dan Data Penelitian}

Sumber data dalam penelitian ini adalah subjek darimana data dapat diperoleh (Arikunto, 2010:172). Menurut Moleong (2013:157) sumber data utama penelitian kualitatif terdiri dari katakata dan tindakan, selebihnya bersifat sebagai data tambahan seperti dokumen dan lain-lain. Data adalah seluruh informasi empiris dan dokumentatif yang diperoleh di lapangan sebagai pendukung kearah konstruksi ilmu secara ilmiah dan akademis (Sugiyono, 2013:4). Data adalah hasil pencatatan penelitian, baik yang berupa fakta-fakta ataupun tindakan, dan atau sumber lain yang berbentuk tulisan.

Dapat penulis simpulkan bahwa sumber data dalam penelitian ini adalah naskah drama Nenek Tercinta karya Arifin C. Noer dan naskah drama adaptasi teater Sukma SMK N 2 Semarang yang di dalamnya terdapat unsur-unsur instrinsik dan ekstrinsik. Wujud data dalam penelitian ini adalah data tulis berupa dialog, kata, kalimat, dan hasil analisis berupa perbedaan alur dalam naskah drama Nenek Tercinta karya Arifin C. Noer dan pertunjukannya.

\section{Teknik Pengumpulan Data}

Pengumpulan data dengan menggunakan metode studi pustaka yaitu menjadikan buku atau pustaka yang terdiri dari kajian: inventarisasi, pencatatan, komulasi (pengumpulan pendapat), dan interpretasi (menafsirkan). Menurut Nazir (1998:112) metode kepustakaan adalah penelitian yang dilakukan di kamar kerja peneliti atau ruang perpustakaan.

Peneliti memperoleh data dan informasi tentang objek penelitiannya lewat buku-buku atau alat-alat audio visual lainnya. Metode studi pustaka digunakan untuk memperoleh teori-teori dan data-data yang relevan dengan penelitian yakni berupa perbedaan alur antara naskah drama Nenek Tercinta karya Arifin C. Noer dan pertunjukannya.

Teknik pengumpulan data juga menggunakan teknik dokumentasi. Menurut Arikunto 
(2006:158) dokumentasi adalah mencari dan mengumpulkan data mengenai hal-hal yang berupa catatan, transkrip, buku, surat kabar, majalah, notulen, rapot, agenda dan sebagainya. Teknik ini digunakan untuk mengumpulkan segala informasi berupa gambar dan video pementasan drama Nenek Tercinta karya Arifin C. Noer.

\section{Teknik Analisis Data}

Analisis perbedaan alur antara naskah drama Nenek Tercinta karya Arifin C. Noer dan pertunjukannya, peneliti menyediakan data yang berupa kutipan peristiwa yang dialami oleh tokohtokoh yang berisikan hal-hal yang bersifat ambigu. Setelah data terkumpul, lalu dianalisis untuk mengetahui hal-hal ambiguitas tersebut yang berada dalam naskah drama.

\section{Teknik Penyajian Hasil Analisis Data}

Teknik penyajian analisis data yang digunakan dalam penelitian ini dengan langkah-langkah ilmiah, yakni 1) merumuskan serta mendefinisikan masalah; 2) mengadakan studi perpustakaan; 3) mengumpulkan data; 4) menyusun, menganalisis, dan memberikan interpretasi; 5) membuat generalisasi dan kesimpulan; dan 6) menyusun laporan ilmiah.

Hasil analisis data berisi paparan tentang segala hal yang dimaksud agar penjelasan tentang kaidah yang ditentukan lebih terperinci dan terurai. Penyajian hasil analisis data dilakukan secara deskriptif dengan menggunakan kata-kata biasa tanpa disertai dengan lambang. Pemaparan hasil analisis data berupa perbedaan alur antara naskah drama Nenek Tercinta karya Arifin C. Noer dan pertunjukannya.

\section{PENUTUP}

Perbedaan alur antara naskah drama Nenek Tercinta karya Arifin C. Noer dan pertunjukannya ditunjukkan melalui peristiwa-peristiwa yang dilakukan tokoh-tokoh dalam naskah drama dan pertunjukannya. Perbedaan tersebut meliputi: perbedaan dalam alur dari segi mutu dan alur berdasarkan pengkhirannya. Alur dari segi mutu, meliputi: alur erat dan alur longgar. Alur berdasarkan pengakhirannya, meliputi alur tertutup dan alur terbuka.

Naskah drama Nenek Tercinta karya Arifin C. Noer memiliki alur erat, di mana jalinan peristiwa sangat padu dan tidak meninggalkan salah satu unsur pembentukan alur: penampilan masalah, perumitan (konflik), puncak masalah (klimaks), peleraian, dan kesimpulan cerita, sedangkan pada pertunjukannya alur yang digunakan adalah alur longgar dengan meninggalkan salah satu peristiwa penting yaitu keberadaan dukun sebagai perumitan (konflik).

Berdasarkan pengakhirannya, naskah drama Nenek Tercinta karya Arifin C. Noer alur yang digunakan adalah alur tertutup di mana cerita hanya sampai kepada dukun yang pamit karena sudah menyelesaikan urusan dan menyakan bahwa yang berkuasa adalah dalang dari segala dalang, sedangkan naskah pertunjukannya menggunakan alur terbuka yang akhir ceritanya diserahkan kepada penonton. 


\section{DAFTAR PUSTAKA}

Arikunto, S. (2006). Metodelogi Penelitian. Yogyakarta: Bina Aksara.

Dewojati, Cahyaningrum. 2010. Drama: Sejarah Teori dan Penerapan. Yogyakarta: Gadjah Mada University Press.

Endraswara, Suwardi. 2008. Metodologi Penelitian Sastra. Yogyakarta: Mada University Press.

Hariyanto, P. 2000. Pengantar Belajar Drama. Yogyakarta: PBSID Universitas Sanata Dharma.

Nazir. 1998. Metode Penelitian. Jakarta : Rineka Cipta.

Ratna, Nyoman Kuntha. 2012. Teori, Metode, dan Teknik Penelitian Sastra. Yogyakarta: Pustaka Pelajar.

Satoto, Soediro. 2012. Analisis Drama dan Teater. Yogyakarta: Penerbit Ombak.

Waluyo, Herman J. 2001. Drama: Teori dan Pengajaran. Yogyakarta: Hanindita Graha Widya.

Yudiaryani. 2015. WS Rendra dan Teater Mini Kata. Yogyakarta: Galang Pustaka. 